\title{
Effect of four different commercial diets on growth perfomance of the cichlid fish, Oreochromis niloticus fingerlings
}

\author{
Hassan M. Khalaf Allah ${ }^{1}$, Mohamed O. Abdel-Ghany ${ }^{2}$ and \\ Mohamed M. Abu-Zaid ${ }^{1}$ \\ 1- Marine Biology and Icthiology branch, Zoology Department, Faculty of Science, \\ Al-Azhar University \\ 2- General Authority of Fish Resources Development, Cairo.
}

\section{ABSTRACT}

The present study deals with the effect of four commercially prepared diets on the length-weight relationship, condition factors, growth performance and feed utilization of the cichlid fish, Oreochromis niloticus fingerling reared in glass aquaria. The major components of diets included proteins, fats and carbohydrates of each feed type. The diets were analyzed for verification of values written on its commercial label. Data showed that, the standard length of the fish fed on the different diets did not vary significantly where it ranges between $6.28 \pm 0.9 \mathrm{~cm}$ in diet II to $6.66 \pm 0.8$ $\mathrm{cm}$ in diet I. The same pattern of change was also noticed in comparing the weight of fishes fed on the four diets. Data indicated that, fish feeding on diet IV demonstrate the lowest weight being on the average of $8.86 \pm 1.97 \mathrm{gm}$, while, fish feeding on diet I showed the highest weight being averaged $10.37 \pm 3.2 \mathrm{gm}$. The growth of fish is nearly isometric in the first three diets and negative allometric in the fourth one. The values of condition factors are slightly differences among different diets. The highest value (3.46) of coefficient of condition $(\mathrm{k})$ was recorded in the fish fed on diet II and the lowest value (3.09) in the fish fed on diet III. The highest average value (1.07) of the relative condition factor $(\mathrm{kn})$ and the lowest $(0.90)$ were recorded in the fish fed on diet III. The lowest value of total weight gain, average daily gain and specific growth rate were detected in the fish fed on diet IV. The value of feed intake of diet I is better than the values obtained from the other feed diets. The best feed conversion ratio (1.87) was recorded in the fish fed on diet II. The lower protein efficiency ratio $(0.25)$ was recorded with diet IV and the higher protein efficiency ratio $(0.53)$ was recorded with diet II.

Keywords: Dietary composition; growth performance; Oreochromis niloticus

\section{INTRODUCTION}

The aquaculture industry currently accounts for over $45 \%$ of all sea food consumed. That will have been projected to increase to $75 \%$ over the next 20 years (FTU, 2007). In Egypt, the production of fish coming from aquaculture represented about $70 \%$ of the total fish production source (GAFRD, 2010). Fish importance as food source increases with the increase in demands, especially in animal protein (ElKalla et al., 2001 and Azab et al., 2005). In the recent years, a great attention has been paid to establishment of fish farms. These farms could contribute partially in producing the demanded on animal protein sources consumed by human (Azab et al., 2005).

Tilapia is an ideal candidate for worm water aquaculture. They spawn easily in captivity, use a wide variety of natural foods as well as formulated feeds, tolerate poor water quality and grow rapidly at warm temperatures. These attributes, along with 
relatively low input costs have made tilapia widely cultured freshwater fish in tropical and subtropical countries (Biswas et al., 2005; Fasakin et al., 2005; El-Saidy and Gaber, 2005; Borgeson et al., 2006; Tsadik and Bar, 2007; Tahoun, 2007 and AlAbssawy, 2010).

The feeding of prepared diets is a principal factor in aquaculture to increase growth and production of reared fish (Thankur et al., 2004; Liti et al., 2005 and Abdel-Tawwab et al., 2007). Dietary protein is an important aspect in achieving efficient fish production and should accommodate fish requirements due to age/weight. Because protein is the most expensive ingredient in commercially prepared feeds and thus it should be carefully formulated to meet the needs of the cultured organism. Understanding the fish's protein requirement during the growth period is fundamental in fish culture management leading to maximized feed conversion efficiency, cost savings, and reduced nutrient loading into the aquatic ecosystem (Abdel- Tawwab \& Ahmad, 2009 and Al-Abssawy, 2010).

Nile tilapia, Oreochromis niloticus (L.) accepts artificial feeding from hatching and typically shows high survival rates and fast growth (El-Sayed, 2006). The optimum feeding regimes / schedules of cultured fish is an important aspect in achieving efficient production and also could lead to a significant saving in diet cost. The feeding schedule concept was developed taking in to account the changes in the protein requirement and digestibility of cultured fishes (Thoman et al., 2004; Wu et al., 2004; Hossain et al., 2006 and Al-Abssawy, 2010).

Therefore, the aim of the present work is to evaluate the effect of four different commercially prepared diets on some biological aspects of Oreochromis niloticus fingerling reared in glass aquaria including length-weight relationship, condition factors, growth performance and feed utilization.

\section{MATERIAL AND METHODS}

A total of 500 specimens of Nile Tilapia, Oreochromis niloticus fingerling, obtained from fish Hatchery at Abbash of the General Authority for Fish Resources Development during the September, 2010. Fishes were transported to the animal facility at Faculty of Science; Al-Azhar University in large plastic bags and then acclimatized for one week in well aerated stock aquaria of 250 liters capacity. Fishes were fed daily on a commercial fish diet and any fish with abnormal appearance or behavior was excluded.

In the laboratory fishes were grouped randomly in 12 groups of 30 fish each. Each fish group was separated in experimental aquarium 90 liters capacity $(100 X 40 X 30 \mathrm{~cm})$. Four different commercial diets (I, II, III and IV) were used in feeding fishes three tanks each. The basic diets were obtained from El-Morshedy factory (feed Diet I, II), Berseq factory (feed Diet III), El-Sayieda Aisha market (feed Diet IV). The tanks were provided with aeration, change of water weekly was carried out and the aquaria were cleaned regularly with add one drop per liter of $1 \%$ methylene blue for each tank. After adaptation was completed, fish in each aquarium were weighed and their initial weights were recorded. Fish in each aquarium were fed twice daily, six days a week. Fish were fed at a rate of $3 \%$ of fresh body weight. The experiment was conducted for 12 weeks and fishes were weighed and measured weekly.

Proximate analysis of protein and lipid in each of the experimental diets were performed according to standard AOAC (2000) methods. 


\section{Biological data:}

\section{Length-weight relationship:}

Standard lengths of ten samples of each aquarium were measured weekly to the nearest millimeter using Varner caliper. The body weight of the same samples was also determined to the nearest 0.1 gram and recorded. Length-weight relationship was determined by using power equation or its logarithmic modification according to the followings methods as the follows:

Where:

$$
\log W=\log a \pm b \log L(\text { Lagler, 1956) }
$$

$\mathrm{W}=$ Weight of the fish in gram.

$\mathrm{L}=$ standard length in centimeter.

$\mathrm{a}$ and $\mathrm{b}=$ constants, whose values are estimated by the least square method. By grouping the fish in $10 \mathrm{~mm}$ length groups the empirical and calculated were determined.

\section{Condition factor:}

Condition factor $(\mathrm{k})$, which measures the well-being of fish was calculated from equation proposed by Hile (1936) as the follows:

$$
\mathrm{K}=100 \mathrm{~W} / \mathrm{L} 3
$$

Where:

$\mathrm{W}=$ fish weight in gram.

$\mathrm{L}=$ fish length in centimeter

The relative condition factor $(\mathrm{Kn})$ was determined by the following formula:

Where:

$$
\mathrm{Kn}=\mathrm{W} / \mathrm{w}
$$

$\mathrm{W}=$ fish weight in gram.

$\mathrm{w}=$ calculated weight estimated from the length-weight relationship.

\section{Growth performance:}

Total weight gain, average daily gain, specific growth rate, feed conversion ratio protein and energy utilization was determined according to Recker, (1975) and castell \& Tiews, (1980) as follow:

(1) Total weight gain $(\mathrm{g} / \mathrm{fish})=(\mathrm{WT}-\mathrm{WI})$

Where:

$\mathrm{WT}=$ final means weight of fish in grams.

$\mathrm{WI}=$ initial means weight of fish in grams.

(2) Average daily gain (ADG) (g/fish/day) = total gain/ duration period.

(3) Specific growth rate $(\mathrm{SGR}) \%$ / day $)=100 \times(\mathrm{Ln}$ WT- Ln WI $) /$ duration period . Where: $\mathrm{Ln}=$ Natural $\log$ and $\mathrm{n}$ is the duration period in days.

\section{Nutrient utilization parameters:}

(1) Feed conversation ratio $(\mathrm{FCR})=$ dry matter intake $(\mathrm{g}) /$ total gain $(\mathrm{g})$.

(2)Protein efficiency ratio $($ PER $)=$ total gain $(\mathrm{g}) /$ protein intake $(\mathrm{g})$.

(3)Protein productive value $(\mathrm{PPV} \%)=(\mathrm{PT}-\mathrm{PI}) \times 100 /$ protein intake $(\mathrm{g})$.

Where:

$\mathrm{PT}=$ protein content in fish carcass at the end.

$\mathrm{PI}=$ protein content at the start.

\section{RESULTS}

Results of the analysis of the composition and characteristics of ingredients of the four tested diets are given in Table (1). Data showed that, the percentage of crude 
protein varied from 27.7 to $30.7 \%$ in diet I and IV respectively. In addition, the amount of fats present in the experimental diets expressed as ether extract (mg/g) ranged between 5.02 to $19.64 \%$ in diets number I and IV respectively.

Table 1: Percentage composition and proximate analysis of the experimental diets contain different dietary composition.

\begin{tabular}{|c|c|c|c|c|}
\hline \multirow{2}{*}{ Items } & \multicolumn{4}{|c|}{ Diets } \\
\cline { 2 - 5 } & I & II & III & IV \\
\hline Fish meal & 30 & 25 & 30 & 10 \\
\hline Soyben meal & 20 & 20 & 25 & 5 \\
\hline Wheat bran & 15 & 20 & 15 & 25 \\
\hline Yellow corn & 25 & 25 & 20 & 50 \\
\hline meet \& bone meal & 5 & 5 & 5 & 5 \\
\hline Gelatian & 0 & 0 & 0 & 4 \\
\hline Glutofed & 0 & 3 & 0 & 0 \\
\hline Molath & 3 & 0 & 3 & 0 \\
\hline Vitamin mixture & 1 & 1 & 1 & 0 \\
\hline Mineral mixtur & 1 & 1 & 1 & 1 \\
\hline \multicolumn{5}{|c|}{ Proximate analysis (\%dry weight) } \\
\hline Dray matter & 94.11 & 94.36 & 95.83 & 96.34 \\
\hline Crude protien & 27.74 & 27.87 & 28.45 & 30.77 \\
\hline Ether extract & 5.02 & 6.99 & 12.77 & 19.64 \\
\hline
\end{tabular}

\section{Growth studies:}

\section{A- Length-Weigh relationship}

Results of length weight relationship of $O$. niloticus fingerling reared in glass aquaria and fed with diet I, II, III and IV are graphically represented in figure (1A, B, C \& D).

\section{1- Length-Weigh relationship of $O$. niloticus, fed on ration I:}

Data in figure (1A) show that, the weight of the fish increases gradually with the increasing length of the fish. From the other angle, the length- weigh relationship of the fish was logarithmically transformed to give the straight-line relationship. Consequently, the values of $\mathrm{a}$ and $\mathrm{b}$ were -1.38 and 2.89 respectively. Thus, the length-weight relationship of this treatment is expressed by the following equation:

$$
\log _{w}=-1.38+2.89 \log _{\mathrm{L}}
$$

From the above-mentioned equation, it is clear that, the growth of fish is nearly isometric. The $b$ value is around the ideal. The correlation coefficient $(r)$ is statistically highly significant (0.996).

\section{2-Length-Weigh relationship of $O$. niloticus, fed on ration II:}

Data in figure (1B) show that, the weight of the fish increases gradually with the increasing length of the fish. From the other angle, the length-weight relationship of the fish was logarithmically transformed to give the straight-line relationship. Consequently, the values of $\mathrm{a}$ and $\mathrm{b}$ were -1.32 and 2.83 respectively. Thus, the length-weight relationship of this treatment is expressed by the following equation:

$$
\log w=-1.32+2.83 \log \mathrm{L}
$$

From the above-mentioned equation, it is clear that, the growth of fish is nearly isometric. The $b$ value is around the ideal. The correlation coefficient ( $r$ ) is statistically highly significant (0.9968).

\section{3- Length-Weigh relationship of $O$. niloticus, fed on ration III:}

Data in figure (1C) show that, the weight of the fish increases gradually with the increasing length of the fish. From the other angle, the length-Weigh relationship 
of the fish was logarithmically transformed to give the straight-line relationship. Consequently, the values of $\mathrm{a}$ and $\mathrm{b}$ were -1.39 and 2.88 respectively. Thus, the length-weight relationship of this treatment is expressed by the following equation:

$\log w=-1.39+2.88 \log \mathrm{L}$

From the above-mentioned equation, it is clear that, the growth of fish is nearly isometric. The $b$ value is nearly ideal. The correlation coefficient $(r)$ is statistically highly significant (0.993).

\section{4- Length-Weigh relationship of $O$. niloticus, fed on ration IV:}

Data in figure (1D) show that, the weight of the fish increases gradually with the increasing length of fish. From the other angle, the length-Weigh relationship of the fish was logarithmically transformed to give the straight-line relationship. Consequently, the values of $\mathrm{a}$ and $\mathrm{b}$ were -0.91 and 2.31 respectively. Thus, the length-weight relationship of this treatment is expressed by the following equation:

$$
\log \mathrm{w}=-0.91+2.31 \log \mathrm{L}
$$

From the above-mentioned equation, it is clear that, the growth of fish is negative allometric. The $\mathrm{b}$ value is more less than the ideal. The correlation coefficient $(r)$ is statistically highly significant (0.993).

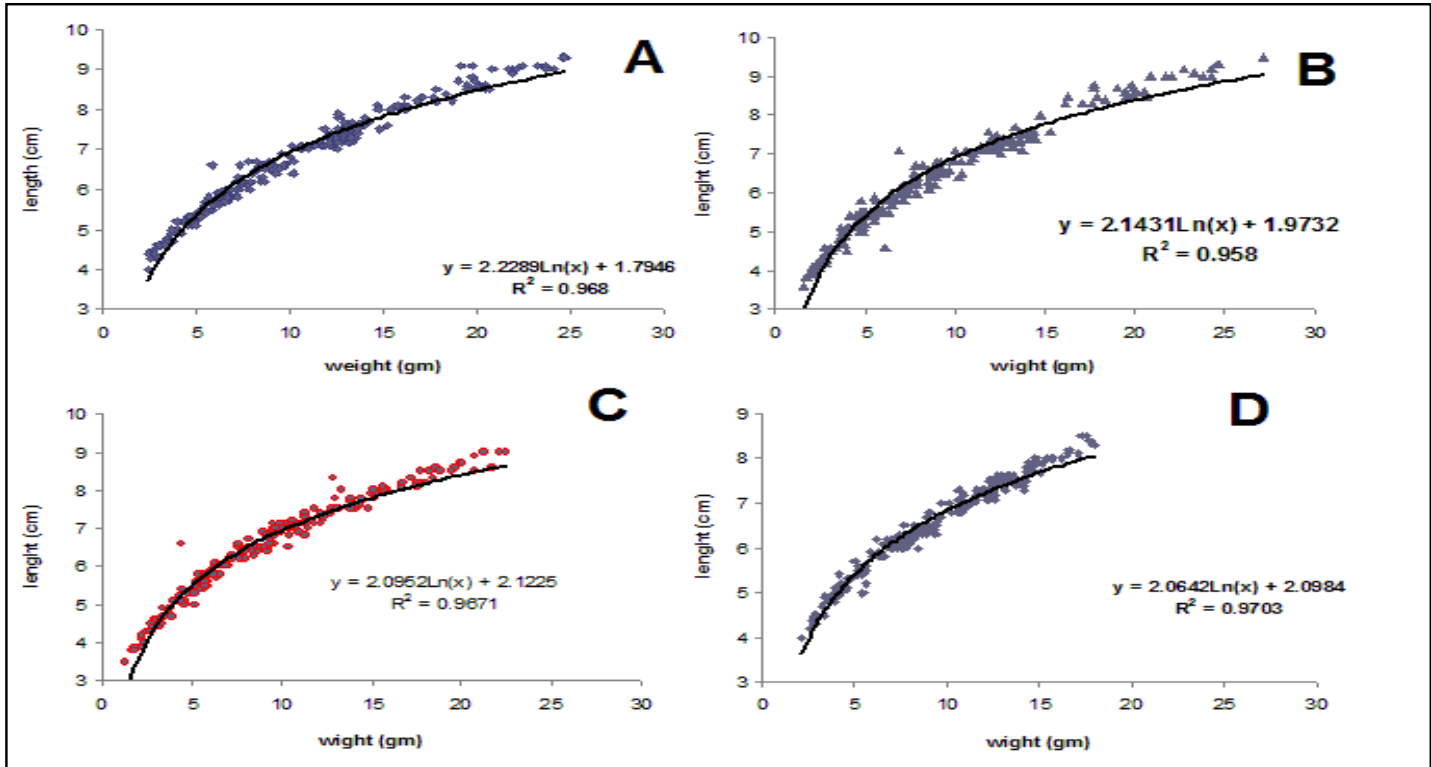

Fig. 1: Length-Weigh relationship of $O$. niloticus reared in glass aquaria and fed on ration I (A), ration II (B), ration III (C), ration IV (D).

\section{B- Condition factors of $O$. niloticus, reared in glass aquaria:}

Results of the composite coefficient of condition (k) and the relative condition factor (kn) of $O$. niloticus fingerling as affected with type of diets are given in (Fig. 2).

Data revealed that, the values of condition factors are slightly different among different feed rations. The highest value (3.46) of coefficient of condition (k) was recorded with the fish fed on ration II and the lowest value (3.09) with the fish fed on ration III. The coefficient of condition $(\mathrm{k})$ average values were slightly decreased among different treatments; being 3.46, 3.36, 3.34 and 3.28 respectively in the fish fed on ration II, ration I, ration IV and ration III respectively (Fig. 2).

The highest average value (1.07) of the relative condition factor $(\mathrm{kn})$ and the lowest $(0.90)$ were recorded in the fish fed on Ration III. The average value of relative 
condition factor $(\mathrm{kn})$ were slightly decreased among different treatments; being (1.00, $0.99,0.99$ and 0.97$)$ respectively in the fish fed on ration III, ration II, ration I and ration IV (Fig. 2).

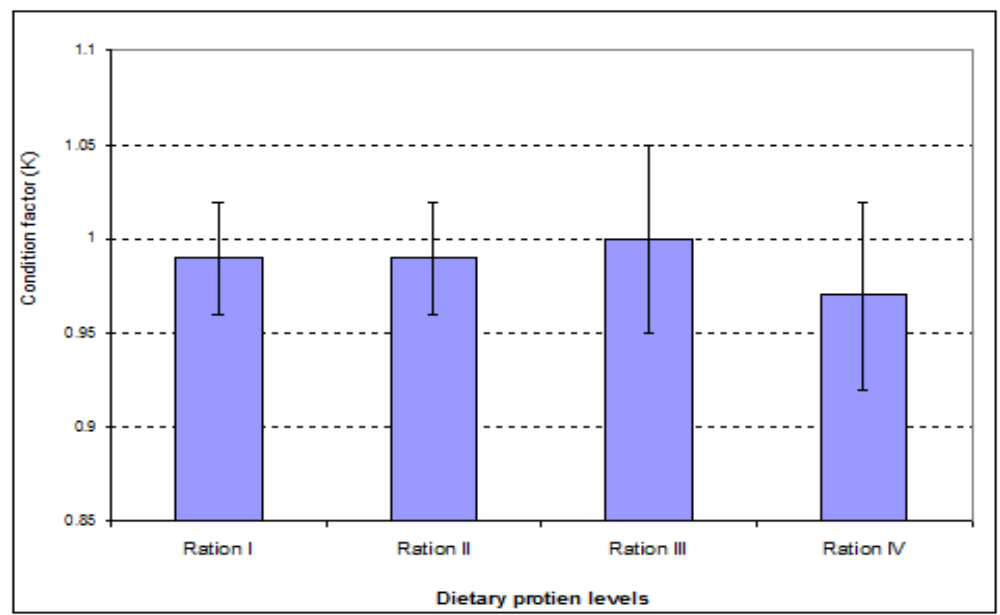

Fig. 2: Effect of different rations on the condition factors of $O$. niloticus, reared in glass aquaria.

\section{C- Growth performance and nutrient utilization parameters:}

Effect of tested rations on initial and final body weight, total weight gain, average daily gain (ADG g/fish/day), specific growth (SGR\%/day), feed intake(FI $\mathrm{gm} /$ fish), feed conversion ratio (FCR), protein efficiency ratio (PER), and protein productive value (PPV\%) are shown in Table (2).

Table 2: Growth performance and nutrient utilization parameters of $O$. niloticus, fed on different feed rations.

\begin{tabular}{|c|c|c|c|c|}
\hline \multirow{2}{*}{ Item } & \multicolumn{4}{|c|}{ Feed rations } \\
\cline { 2 - 5 } & Ration I & Ration II & Ration III & Ration IV \\
\hline $\begin{array}{c}\text { Initial live weight } \\
\text { (g/fish) }\end{array}$ & $4.41 \pm 1.95$ & $3.31 \pm 1.85$ & $3.4 \pm 1.23$ & $4.81 \pm 1.58$ \\
\hline $\begin{array}{c}\text { Final live weight } \\
\text { (g/fish) }\end{array}$ & $13.37 \pm 4.67$ & $13.18 \pm 6.86$ & $13.4 \pm 4.48$ & $11.8 \pm 2.64$ \\
\hline Weight gain (g/fish) & $8.96 \pm 3.31$ & $9.87 \pm 4.35$ & $10 \pm 2.85$ & $6.99 \pm 2.11$ \\
\hline $\begin{array}{c}\text { Average daily gain } \\
\text { (g/day/fish) }\end{array}$ & 0.10 & 0.11 & 0.11 & 0.08 \\
\hline $\begin{array}{c}\text { Specific growth rate } \\
\text { (\%day) }\end{array}$ & 1.32 & 1.64 & 1.63 & 1.05 \\
\hline Feed intake (FI) & 28.16 & 18.50 & 26.14 & 27.98 \\
\hline $\begin{array}{c}\text { Feed conversion ratio } \\
\text { (FCR) }\end{array}$ & 3.14 & 1.87 & 2.61 & 4 \\
\hline $\begin{array}{c}\text { Protein efficiency ratio } \\
\text { (PER) }\end{array}$ & 0.38 & 0.53 & 0.38 & 0.25 \\
\hline $\begin{array}{c}\text { Protein productive } \\
\text { value (PPV \%) }\end{array}$ & 13.31 & 4.27 & 7.45 & 17.26 \\
\hline
\end{tabular}

Data show that, the total weight gain of Nile tilapia, $O$. niloticus, fingerling improved in general with the increasing dietary protein level up to ration III compared with fish group fed on diet I, diet II and diet IV; being $10 \pm 2.85$ in the former and $8.96 \pm 3.31,9.87 \pm 4.35$ and $6.99 \pm 2.11$ respectively in the latter. The lowest value of total weight gain $(6.99 \pm 2.11)$ was detected in the fish fed on diet IV. The same trend was observed with average daily gain and specific growth rate. 
The value of feed intake ( $\mathrm{g} / \mathrm{fish}$ ) of ration $\mathrm{I}$ is better than the values obtained from the other rations. The best feed conversion ratio (1.87) was recorded in the fish fed on ration II. The higher protein efficiency ratio (PER) was recorded with ration II $(0.53)$ and the lower protein efficiency ratio $(0.25)$ was recorded with ration IV. Efficiency of protein utilization in terms of protein productive values (PPV \%) recorded among ration I, ration II, ration III and ration IV were 13.31, 4.27, 7.45 and 17.26 respectively.

\section{DISCUSSION}

Tilapia, are considered as the best species for culture, because of their high tolerance to adverse environmental conditions, ease of reproduction, their fast growth and potential for domestication (El-Sayed, 1999).

Fish growth has long been an interesting subject for aqua culturists and fisheries. Consequently most researches, experimental approach and that of field studies, have been concentrated on commercially important species. The condition factors are based on the hypothesis that, the heavier fish of a given length is in better condition. They are often used to compare the differences related to ecological and biological factors such as fatness, sex, mortality, feeding conditions and gonad weight (Bagenal and Tesch, 1978; Al-Abssawy, 2010 and Basusta et al., 2013). Mahdi et al., (1973) studied the length-weight relation of Tilapia in saline, fresh and brackish water ponds and stated that, the length-weight relationship was found to be the best method for studying age groups.

The present study showed that, the weight of the fish O.niloticus increases to power greater than the -cube of the length and this indicates that, the shape change rapidly with the increasing length. There is a close fit between the actual and calculated weights. Similar observations were detected by Khallaf and Alne-na-ei (1995) who studied age and growth of O. niloticus in Bahr shebeen Canal and showed that, the value of condition factor increased with increasing fish length which differs with the present study. It may be due to location and environmental conditions between Bahr Shebeen Canal and laboratory conditions.

In the present study the (b) value was around 3 except feed ration IV. Similar observations were noticed for the same species by Mosaad (1990) at Lake Qarun (2.9); El-Zarka (1961) at Lake Edku (3.06) and Lake Qarum (3.09); and differ at Lake Borollus (3.21).

The present study indicated that, the weight increases with the increasing length of this fish. This result was nearly similar to Khalaf-allah (2001), who studied the length-weight relationship and condition factors and approved that, all fishes; the exponent " $b$ " in the fish is around the ideal. Composite coefficient " $\mathrm{k}$ " and the relative condition factor "kn" are varied significantly with the fish size.

In the present study, the highly best growth is recorded in the fishes fed on ration $I(b=2.89)$. It may be due to decrease of lipid level in the diet. In this connection, Soliman (2005) and Al-Abssawy (2010) revealed that, the correlation coefficient " $\mathrm{r}$ " was statically highly significant; being 0.9097 for O. niloticus, which uncompleted agreement to the current study results.

The condition factors are based on the hypothesis that, the heavier fish of a given length is in better condition. They are often used to compare the differences related to ecological and biological factors such as fatness, sex, mortality, feeding conditions and gonad weight (Bagenal and Tesch, 1978 and Al-Abssawy, 2010). 
However, the annual condition factor reported by Soliman (2005) for the four species can be arranged in the following sequence, T. zilli $(2.05)>S$. galilaeus $(2.05)$ $>$ O. niloticus $(2)>$ O. aureus (1.73). These results are lower than that recorded in the current study. It may be due to the variations of environmental conditions between natural habitat and laboratory.

Optimization of feed quality for fish farming is important for economical assessment as well as biological, environmental and health reasons. The impact of feed on growth and feed conversion will mainly depend on the used ingredients and on their quality (Tacon, 1994). Also, processing of food plays an important role in food quality, safety, storage and characteristics of specific food item (Chen et al., 1999). Feeding represent over $50 \%$ of the operational costs of aquaculture (Jauncey \& Ross, 1982; Tacon, 1993 and El-sayed, 1999).

In the present study, the best feed conversion ratio (1.87) was recorded in fish fed on ration II. This result was higher than that recorded in the same species in other farms, El-Shebly (1991\& 1998) recorded food conversion of 1.8 in Serow Fish-Farm and 1.21 in fresh water fish farm at Manzalah region which indicates the bad foods are used in the present experiment. The diet of fishes must be balanced and contain the primary or basic food components including protein, carbohydrates and lipids. The amounts of these substances were differences for different species of fishes. Vitamins and minerals are also required for growth, sustenance and replacement of tissues as well as for normal metabolism (Villegas, 1975).

The present study revealed that, the average values of final body weight, total weight gain and average daily gain (ADG g/fish/day) increases with the increasing dietary protein levels except in ration IV. It may be due to the pad source of protein in the feed ration IV. Results came in close disagreement with those obtained by Shiau and Hung (1990), who found that the protein energy ratio required for the better growth of hybrid Tilapia fed on a diet containing $21 \%$ crude protein attained $67.74 \mathrm{mg}$ protein/kcal.

In the present study, the feed intake and feed conversion ratio showed no significant differences. The tested diets tend to be very low benefits for growth of fish. This result is differs with observations detected by Khater and Dawah (2008) and in agreement with that of Al-Abssawy (2010). Who reported that growth of molds on stored grains reduces its quality because of diminished sprouting discoloration, changes in taste as well as loss in nutrient value. Also, these results are similar to those observed by many investigators on the growth suppression in fish fed rancid diets (Yildirim et al., 2000; Tuan et al., 2002 \& 2003 and Manning et al.,2003 and Azab et al., 2005).

However, these results are in disagreement with El-Sagheer (2001) who reported that, the increasing dietary protein level from $25 \%$ to $32 \%$ increased growth performance and nutrient utilization of Tilapia. Bahnasawy (2009), however, found that, the diet containing 30\% crude protein is considered optimal for growth of monosex Nile Tilapia of $2.5 \mathrm{~g}$ average initial weight.

In the present study, it was found that the feed rations III were improved weight gain. These results were similar to the recommended values (25\% crude protein) for fresh water fish in several other countries (Clark et al., 1990; Shiau and Hung., 1990 Khater and Dawah, 2008 and Al-Abssawy, 2010).

From the previous results, it was clear that, using length-weight relationship, condition factors, growth performance and feed utilization is a must for determination of the quality of the fish feed. For example, the analysis of protein content alone is not enough, thus the $30 \%$ protein diet did not improve growth performance of $O$. 
mloticus. The protein quality and its amino acids profiler as well as its contents of essential amino acids and its digestibility are more important parameters to judge the ration quality.

So it is recommended that a set of procedures applied in the present work should be used in testing the fish feed prior to application in the fish farms (aquaculture).

\section{REFERENCES}

Abdel-Tawwab, M., Abdel-ghany, A. E., Ahmad, M. H. (2007): Effect of feed supplementation on water properties, phytoplankton community structure and the growth of Nile tilapia, Oreochromis niloticus (L.), common carp, Cyprinus carpio L., and silver carp, Hypophthalmichthys molitrix V. polycultured in fertilized earthen ponds. J. Appl. Aquacult., 19(1): 1-24.

Abdel-Tawwab, M. and Ahmad, M. H. (2009): Effect of dietary protein regime during the growing period on growth performance, feed utilization and whole-body chemical composition of Nile Tilapia, Oreochromis niloticus (L.). Aquacult. Res. 40: 1532-1537.

Al-Abssawy, A. N. M. (2010): Nutritional requirements for Nile tilapia, Oreochromis niloticus, cultivated in El-Max research station with special references to their growth and feeding habits. M. Sc. Thesis, zoology Department, faculty of science, Al-Azahra University, Cairo, $317 \mathrm{pp}$.

AOAC (2000): Association of Official Analtical Chemisits, Official methods of analysis, $17^{\text {th }}$ Ed. Washington, DC., USA.

Azab, A.M; Shoman, H.M.; Abd Al-Hakim, N.F.and Mostafa, M.G. (2005): Effect of diet processing and storage on growth and production of the Nile tilapia, Oreochromis niloticus. African J. Biol. sci., 1(1): 89-99.

Bagenal, T. B. and Tesch, F. W. (1978): Age and growth in methods for assessment of fish production in freshwater. (W.E. Ricker, ed.) pp. 101-113.

Bahnasawy, M. H. (2009): Effect of Dietary Protein Levels on Growth Performance and Body Composition of Monosex Nile Tilapia, Oreochromis niloticus L. Reared in Fertilized Tanks .Pakistan J. Nut., 8 (5): 674-678.

Basusta, A.; Basusta, N.; Calta, M.; Ozer, E. I. and Girgin, H. (2013): Length-Weight relationship and condition factor of spiny gurnard (Lepidotrigla dieuzeidei Blanc and Hureau, 1973) inhabiting northeast Mediterranean sea. Journal of Animal and Veterinary Advances 12 (2): 212-214.

Biswas, A. K.; Morita, T.; Yoshizaki, G.; Maita, M. and Takeuchi, T. (2005): Control of reproduction in Nile tilapia, Oreochromis niloticus (L.) by photoperiod manipulation. Aquacult., 243:229-239.

Borgeson, T. L.; Racz, V.; Wilkie, D. C.; White, L. J. and Drew, M. D. (2006): Effect of replacing fishmeal and oil with simple or complex mixtures of vegetable ingredients in diets fed to Nile Tilapia (Oreochromis niloticus). Aquacult. Nut., 12: 141-149.

Castell and Tiews (1980): Report of the EIFAC, IUNS and ICES Working Group on the Standardization of Methodology in Fish Research. Hamburg, FRG, Germany, 21-23 March. IFAC Tech. Pap. (3) 24.

Chen, y.; Zhu, N.; Yulo, C.; Wang, M. and Ho, C. T. (1999): Process-induced health promoting substance in foods. Food Rev. Int., 15(4): 473 - 501. 
Clark, A. E., Watanabe, W.O., Olla, B. L. and Wicklund, R. I., (1990): Growth, feed conversion and protein utilization of Florida red Tilapia fed isocaloric diets with different protein levels in sea water pools. Aquacult., 88(1): 75-85.

El-Saidy, D. M. S. and Gaber, M. M. A. (2005): Effect of dietary protein levels and feeding rates on growth performance, production traits and body composition of Nile Tilapia, (Oreochromis niloticus) (L.) cultured in concrete tanks. Aquacult. Res., 36 (2): $163-171$.

El- Sayed, A. F. M. (1999): Alternative dietary protein sources for farmed Tilapia (Oreochromis sp). Aquacult., 179: 149-168.

El-Kalla, H. R.; Enaber, M. A. and Thabet, M. G. M. (2001): Fish farms economics in Egypt (A field study in Dakhalia). J. Agrie.Sci. Mansoura Univ., 26(6):3689-3700.

El-Sagheer, F. H., (2001): Effect of stocking densities, protein levels and feeding frequencies on growth and production of Tilapia monosex in earthen ponds. $\mathrm{Ph} . \mathrm{D}$. Alexandria University.

El-Sayed, A. F. M. (2006): Tilapia Culture. CABI Publishing, CABI International, Willingford, Oxfordshire, United Kingdom.

El-Shebly, A. A. (1991): Effect of fertilizers on rearing of fish in Serow Fish-Farm. M.Sc. Thesis, Faculty of Science, Mansoura University, 222pp.

El-Shebly, A. A. (1998): Studies on Growth and production of Oreochromis niloticus in semi-intensive fish culture. J. Egypt. Ger. Soc. Zool., vol. 27(B): 69-80.

El-Zarka, S. (1961): Tilapia fisheries investigation in Egyption lakes. II- A biological study of the fisheries of Tilapia zillii in Lake Qaroun, Egypt. Notes and Memories. Alexandria Institute of Hydro- Biology, No.66.

Fasakin, E. A.; Serwata, R. D. and Davies. S. J. (2005): Comparative utilization of rendered animal derived products with or without composite mixture of soybean meal in hybrid Tilapia (Oreochromis niloticus $X$ Oreochromis mossambicus) diets. Aquacult., 249 (1-4): 329-338.

FTU (2007): Feed Technology Update. Insects offer a promising solution to the protein bottle neck, Volume 2, Issue 6 .

GAFRD (2010): General Authority for Fish Resources Development. Fishery statistic. Egyptian Ministry of Aquaculture.

Hile, R. (1936): Age and growth of the cisscoe, Leveichthys artedi (Lesueur), in the lakes of the Northern high lands, Wisconsin. Bull. Mar. Fish, U.S., Vol. 48 (19): 211-317.

Hossain, M. A.; Ali, M. Z.; Rahman, M. M. and Kader, M. A. (2006): Evaluation of mixed feeding schedules with varying dietary protein content on the growth performances and reduction of cost of production for sutchi catfish, Pangasius Hypophthalmus (Sauvage) with silver carp , Hypophthalmichthys Molitrix (Valenciennes). J. Appl. Aquacult., 18(1): 63-78.

Janncy; K. and Ross, B. (1982): A Guide to Tilapia feeds and feeding. Institute of Aquaculture, University of Stirling, Scotland, United Kingdom.

Khalaf-Allah, H. M. M. (2001): Ecological and biological studies on some fishes in Lake Qarun, Egypt. M.Sc. Thesis, Zool. Dep. Fac. Sci., Al-Azhar Univ., Egypt, pp331.

Khallaf, E. A. and Alne-na-ei, A. A. (1995): A study of age and growth of (Labeo niloticus) (Pisces, Cyprinidae) in Bahr Shebeen Canal. J. Union. Arab BioI., 3 (A): $159-175$.

Khater, A. M. and Dawah, A. M. (2008): Comparative studies on growth performance and survival of Oreochromis niloticus and Oreochromis aureus fry reared on 
different protein levels with natural food. Central Lab. For Aquaculture Research, Abbassa, Agricultural Research Center, Giza, Egypt.

Lagler, K.F. (1956): Fresh Water fishery biology. W.M.C. brown comp., Dubuque, Iowa, $2^{\text {nd }}$ Edition, $421 \mathrm{pp}$.

Liti, D.; Cherop, L.; Munguti, J. and Chhorn, L. (2005): Growth and economic performance of Nile Tilapia (Oreochromis niloticus L.) fed on two formulated diets and two locally available feeds in fertilized ponds. Aqucult. Res., 36: 746752.

Mahdi, M. A.; Rafail, S. Z. and Al-Kholy, A. A. (1973): Biological studies on Sudanese inland fishes. II -Tilapia nilotica (Linnaeus). Bull. Inst. Ocean.Fish. ARE, Vol. 3: 257-274.

Manning, B. B.; Ulloa, R. M.; Li, M. H.; Robinson, E. H. and Rottinghaus, G. E. (2003): Ochratoxin, A fed to channel catfish (Ictalurus punctatus) causes reduced growth and lesions of hepato-pancreatic tissue. Aquacult., 219: 739750 .

Mosaad, M. N. M. (1990): Biological studies on five fish species from Lake Qarun, Egypt. 1- Length-weight relationship and condition factors. Proc. Zool. Soc. A.R.E., 21: 331- 344.

Recker, W. E. (1975): Computation and interpretation of biological statistics of fish populations. Fish. Res. Board Can. Bull., 191, 1-382.

Shiau, S. Y. and Huang, S. L. (1990): Influence of varying energy levels with two protein concentrations in diets for hybrid Tilapia (O. niloticus. \& O. aureus) reared in sea water. Aquacult., (91): 143-152.

Soliman, T. B. H. (2005): Eficiency selectivity of fishing gears and methods in Lake Edku and their effects on the stock of fish populations. M.Sc. Thesis, Fac. Sci., AI- Azhar Univeristy, pp 359.

Tacon, A. G. J. (1993): Feed ingredients for warm water fish. Fish meal and other processed feedstuffs, FAO Fish. Cire. No. 856, FAO, Roma, 64pp.

Tacon, A. G. J. (1994): Feed ingredients for carnivorous fish species Alternatives to fish meal and other fishery resources FAO, Fish Cairo. No.881, Rome, 35pp.

Tahoun, A. M. A. (2007): Studies on some factors affecting the production and reproduction of Nile Tilapia. Ph. D. Thesis, University of Kafr El-sheikh, Egypt.

Thankur, D. P.; Yi, Y.; Diana, J. S. and Ckwei Lin. (2004): Effects of fertilization and feeding strategy on water quality growth performance nutrient utilization and economic return in Nile Tilapia. Pages 529-543. in R Blivar, G. Mair, and K. Fitzsimmons, eds. Proceedings of the Sixth International Symposium of Tilapia in Aquculture, 14-16. August 2004. Philippine International Convention Center, Manila, Philippines.

Thomanetal, E. S.; Davis, D. A. and Arnold, C. R. (2004): Effect of phase feeding decreasing levels of dietary protein on growth and diet utilization of the red drum, Sciaenops ocellatus. J. Appl. AqucuIt., 15(3/4): 127-140.

Tsadik, G. G. and Bar, A. N. (2007): Eftects of feeding, stocking density and waterflow rate on fecundity, spawning frequency and egg quality of Nile Tilapia, Oreochromis niloticus (L.). Aquacult., 272: 380- 388.

Tuan, N. A.; Grizzle, J. M.; Lovell, R. T.; Manning, B. B. and Rottinghaus, G. E. (2002): Growth and hepatic lesions of Nile tilapia (Oreochromis niloticus) fed diets containing aflatoxins $\mathrm{B}_{1}$. Aquacult., 212: 311 - 319 .

Tuan, N. A.; Manning, B. B.; Lovell, R. T. and Rottinghaus, G. E. (2003): Responses of Nile tilapia (Oreochromis niloticus) fed diets containing different concentrations of moniliformin or fuinonisin $\mathrm{B}_{1}$. Aquacult., 217: 515-528. 
Villegas, C. T., (1975): Culture and screening of food organisms as potential larval food for finfish and shellfish. Report Series No. 13. Ministry of Agriculture FAO. September 1975.

Wu, G.; Saoud, I. P.; Miller, C. and Davis, D. A. (2004): The effects of the feeding regime on mixed pond grown channel catfish, Ictalurus punctatus. J. Appl. Aqucult., 15(3/4): 115-125.

Yildirim, M.; Manning, B. B.; Lovell, R. T.; Grizzle, J. M. and Rottinghaus, G. E. (2000): Toxicity of Moniliformin and Fumonisin $B_{1}$. Fed singly and in combination in diets for young channel catfish, lctalurus punctatus. J. W. Aquacult. Soc., 31(4): 599 - 607.

\section{ARABIC SUMMERY}

\section{تأثير أربعه علائق تجارية مختلفة علي نمو وأداء اصبعيات البلطى الأبيض (أوريوكرومس نيلوتيكس) · \\ حسن مشحوت خلف الله' ، محمد عثمان السبد محمد عبدالغتى '، محمد محمود أبوزيد'

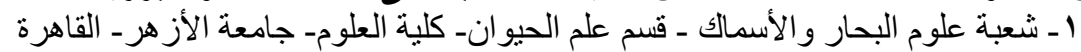 r الهيئه العامة لتنمية الثروة السمكيه}

من اولي المشاكل الخطيره و الهامه في كثير من انحاء العالم هي نقص البروتين الحيو اني اللازم اللغذاء

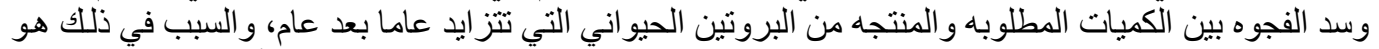

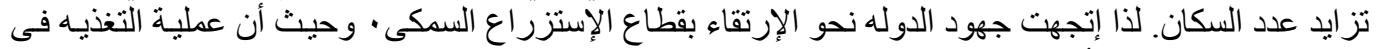

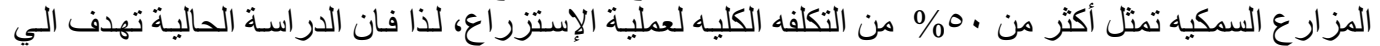

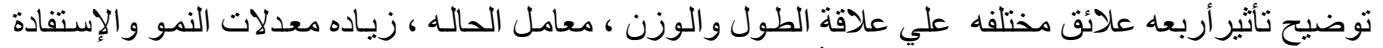

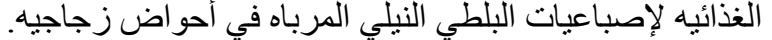

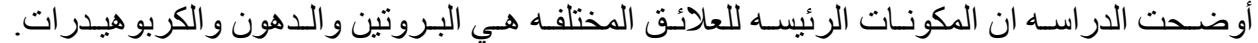

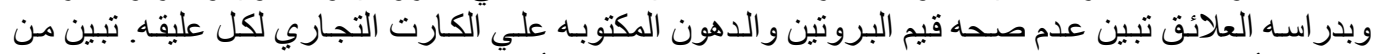

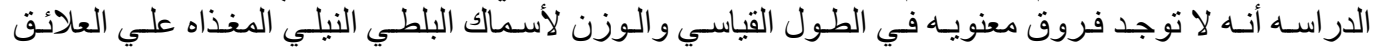

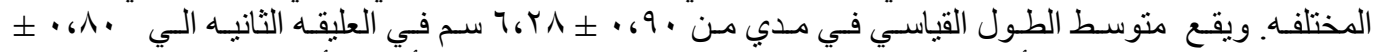

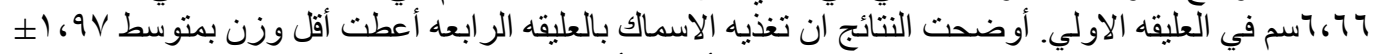

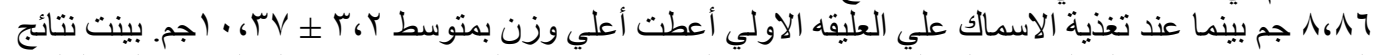

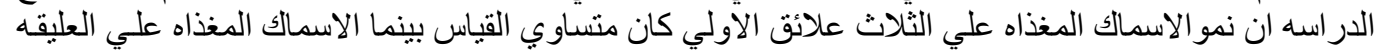

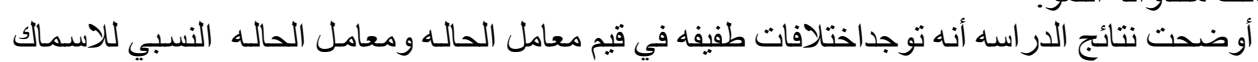

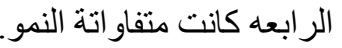

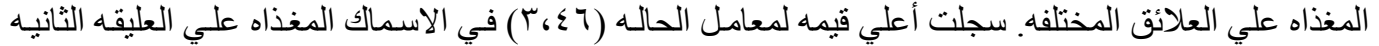

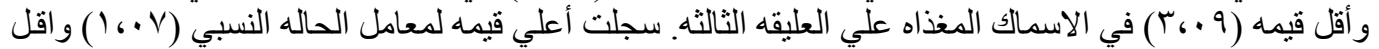

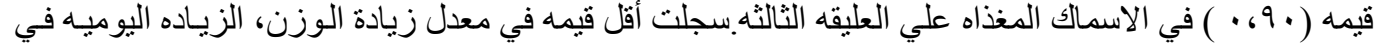

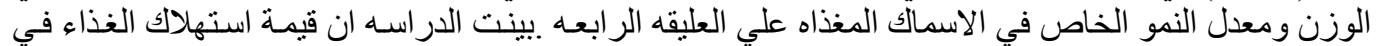

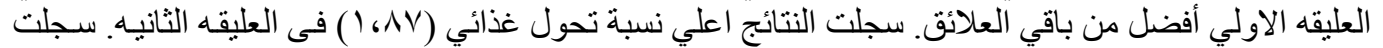

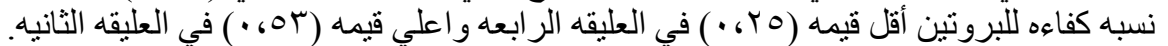

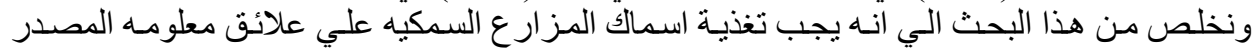

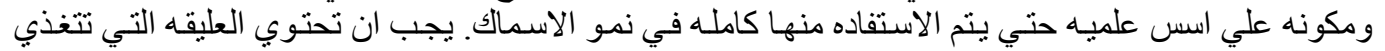

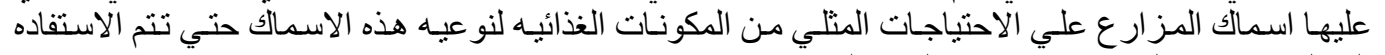
الكامله من حيث العائد الاقتصادي والي القيمه الغذات الئيه. 